INTERNATIONAL JOURNAL OF RESEARCHES IN BIOSCIENCES, AGRICULTURE \& TECHNOLOGY O VISHWASHANTI MULTIPURPOSE SOCIETY (Global Peace Multipurpose Society) R. No. MH-659/13(N) www.vmsindia.org

\title{
SHELF LIFE OF BRADYRHIZOBIUM ON DIFFERENT LIQUID BASED INOCULANTS AND PERFORMANCE ON GROWTH AND YIELD OF SOYBEAN
}

\author{
Das A., Thakur K., Pillai T. and Bramhankar S. \\ College of Agriculture, Nagpur (M.S) India \\ Email: Kdthakur60@gmail.com
}

\begin{abstract}
The present investigation shelf life studies of Bradyrhizobium by using different carriers Saline solution, glycerol, carboxymethyl cellulose, soybean oil, paddy bran oil, mineral oil, lignite powder mixed with 90, 80, 60 and $75 \mathrm{ml}$ Bradyrhizobium broth combination. Shelf life studies indicated significant differences in rhizobial colonies. In field experiment, among all the treatments maximum root length were recorded @ 30 and 45 DAS in $\mathrm{T}_{1}$ i.e. $10 \mathrm{ml}$ saline solution $+90 \mathrm{ml}$ broth $(24.77 \mathrm{~cm} /$ plant, $36.93 \mathrm{~cm} /$ plant $)$ respectively. Maximum nodulation was recorded by $10 \mathrm{ml}$ saline solution $+90 \mathrm{ml}$ Bradyrhizobium broth (13.00). Among 20g CMC $+80 \mathrm{ml}$ Bradyrhizobium broth treatment recorded significantly higher number of nodules (11.36 nodules/ plant) as compared to other treatment. In paper towel method maximum germination percentage was recorded in $10 \mathrm{ml}$ saline solution $+90 \mathrm{ml}$ Bradyrhizobium broth $(86 \%)$ followed by $20 \mathrm{~g} \mathrm{CMC}+80 \mathrm{ml}$ Bradyrhizobium broth treatment $(80.33 \%)$. However root and shoot length was maximum in $10 \mathrm{ml}$ saline solution $+90 \mathrm{ml}$ Bradyrhizobium broth $(11.30 \mathrm{~cm})$ and $(9.20 \mathrm{~cm})$ respectively. The maximum seedling vigour index was 1756 by $10 \mathrm{ml}$ saline solution $+90 \mathrm{ml}$ Bradyrhizobium broth seed treatment.
\end{abstract}

Keywords: Soybean, Vigour index, Inoculants

\section{Introduction:}

Soybean (Glycine max (L.) Merill) owning to high potential plays an important role in boosting oilseed production in the country. Soybean is an important global crop belongs to the family Leguminaceae. The powder carrier based biofertilizers are used since a long time. The traditional nitrogen fixing biofertilizers have suffered from the problems of short shelf life, instability to ambient temperature and laborious large scale application. Whereas liquid inoculants could be produced with minimum labour, space and energy. Also the quantity of inoculum required for application is less as compared to carrier based formulations. It is easier for farmers to handle and apply liquid biofertilizer's formulation which could be considered as one potential strategy for improving the shelf life of biofertilizer. Unlike solid carrier based biofertilizers, liquid formulations allows the manufacturer to include sufficient amount of nutrients, cell protectant and inducers responsible for cell/spore/cyst formation to ensure prolonged shelf life. As being leguminous crop soybean helps in soil enrichment with the atmospherically fixed nitrogen symbiotically available to the succeeding crop. It is estimated that the on an average 20 to $40 \mathrm{~kg}$ nitrogen is fixed symbiotically
(Kunal and Poonam Sharma, 2011). In present study shelf life and performance of liquid based Bradyrhizobium is analysed with following objectives to study the shelf life of Bradyrhizobium on different liquid carriers and the symbiotic relationship on growth and yield of soybean

In the present study Bradyrhizobium japonicum was selected as test organism. It is slow growing bacterium of family Rhizobiaceae. Inoculation of soybean seed with Bradyrhizobium can fix 60 to $80 \mathrm{~kg}$ $\mathrm{N} /$ ha and subsequently increase the nodulation, shoot length, plant height, number of pods and seed yield over control. Solid carriers are difficult to process to consistent characteristics and may not appropriate using with planting equipment used on large scale of field operation (Singleton et al., 2002). Liquid inoculants formulation is one solution to the problems associated with processing of solid carriers. The use of broth culture amended with substances promotes cells survival in the package and after seed treatment. Therefore, liquid inoculants are formed which have been developed to solve the problems associated with processing of solid carriers. 


\section{Material and Methods:}

An experiment entitled "Shelf life of Bradyrhizobium on different liquid based inoculants and performance on growth and yield of soybean" was conducted in Plant Pathology Laboratory, College of Agriculture, Nagpur during the year 2015-2016. The details of material used and the methods adopted during the course of investigation are included in this chapter given under the following heads. The seed of soybean (JS335) was obtained from Central Research Station, Dr. Panjabrao Deshmukh Krishi Vidyapeeth, Akola. Carrier material taken for study viz. saline solution, glycerol, CMC, soybean oil, paddy bran oil, mineral oil, lignite which were procured in ready condition (120 mesh). Seven carriers were tested as carrier material for Bradyrhizobium, they were sterilized at 15 lbs pressure for $3 \mathrm{hrs}$ in an autoclave.

Growth, maintenance and preservation of Bradyrhizobium culture

Pure culture of Bradyrhizobium was maintained on YEMA slants (Graham and Parker, 1967). Sub culturing and checking for purity was done once in two months when stored at $40 \mathrm{C}$ temperature. Bradyrhizobium japonicum broth at $10^{7}$ cells/ml was inoculated with glycerol and lignite. The $\mathrm{p}^{\mathrm{H}}$ of lignite was adjusted to 6.5 to 7 by using calcium carbonate. The samples were drawn at monthly interval up to 180 days to study the shelf life. The treatment details were as follow-

\begin{tabular}{|c|l|}
\hline $\begin{array}{c}\text { Treatment } \\
\text { No. }\end{array}$ & \multicolumn{1}{c|}{ Treatment details } \\
\hline $\mathrm{T}_{1}$ & $\begin{array}{l}\text { 10ml saline solution }+90 \mathrm{ml} \\
\text { Bradyrhizobium broth }\end{array}$ \\
\hline $\mathrm{T}_{2}$ & $\begin{array}{l}\text { 10ml glycerol+ } 90 \mathrm{ml} \text { Bradyrhizobium } \\
\text { broth }\end{array}$ \\
\hline $\mathrm{T}_{3}$ & $\begin{array}{l}20 \mathrm{~g} \text { CMC }+80 \mathrm{ml} \text { Bradyrhizobium } \\
\text { broth }\end{array}$ \\
\hline $\mathrm{T}_{4}$ & $\begin{array}{l}\text { 40ml soybean oil }+60 \mathrm{ml} \\
\text { Bradyrhizobium broth }\end{array}$ \\
\hline $\mathrm{T}_{5}$ & $\begin{array}{l}\text { 40ml paddybran oil }+60 \mathrm{ml} \\
\text { Bradyrhizobium broth }\end{array}$ \\
\hline $\mathrm{T}_{6}$ & $\begin{array}{l}\text { 25 ml mineral oil }+75 \mathrm{ml} \\
\text { Bradyrhizobium broth }\end{array}$ \\
\hline $\mathrm{T}_{7}$ & $\begin{array}{l}\text { Powder base (lignite) } 200 \mathrm{~g}+100 \mathrm{ml} \\
\text { Bradyrhizobium broth }\end{array}$ \\
\hline $\mathrm{T}_{8}$ & Untreated control \\
\hline
\end{tabular}

\section{Inoculation of carriers with Bradyrhizobium inoculants}

Five day old isolated broth culture of Bradyrhizobium japonicum was used for inoculation so as to adjust the moisture level of carrier to $50 \%$ of water holding capacity of the carrier. The carriers after mixing with culture of Bradyrhizobium japonicum were cured at 20-25 C for $48 \mathrm{hrs}$.

In sterilized test tubes with the help of sterilized distilled water blank of $9 \mathrm{ml}$ capacity were prepared. One gram of sample was taken from individual sample into $1^{\text {st }}$ number of water blank to make 1:10 dilution to obtain uniform suspension. Dilution was vigorously shaken mechanically. Soil particles were allowed to settle down. One $\mathrm{ml}$ suspension transfer into second blank with the help of sterilized pipette and shake vigorously from $2^{\text {nd }}$ upto 7 th. One $\mathrm{ml}$ suspension was transferred to sterilized petriplate containing YEMA medium, $10^{-6}$ dilution was used for estimating rhizobial population in all the treatments.

\section{Inoculation of plate}

The sterilized melted medium was poured in previously sterilized petri plates. In each plate $20 \mathrm{ml}$ of medium was poured and rotated with hands for uniform distribution of suspension and allowed to settle down. The plates were incubated at room temperature $28 \pm 2^{\circ} \mathrm{C}$. Shelf life was studied by serial dilution method at monthly interval

\section{Results and Discussion:}

Studies were undertaken on "Shelf life of Bradyrhizobium on different liquid based inoculants and performance on growth and yield of soybean" during the year 2015 in Randomized Block Design (RBD) with eight treatments and three replications using the soybean variety JS-335. The results are presented in tables; photograph and figures are depicted in each head in this chapter.

\section{Rhizobial population in liquid based carrier}

Six carriers viz., saline solution, glycerol, carboxy methyl cellulose, soybean oil, paddy bran oil, mineral oil and lignite powder were mixed individually with broth of Bradyrhizobium japonicum at $10^{7}$ cells $/ \mathrm{ml}$. 
The experiment was set for 180 days. The data obtained is presented in Table 1 .

It was revealed from the data that there were significant differences in rhizobial population at all the intervals. Maximum population was attained with saline solution (60.33 X $10^{7}$ cell $/ \mathrm{ml}$.) and it was found significantly superior over all other treatment at 120 days in respect to other treatment.

Table-1: Rhizobial population (x $10^{7}$ cells $/ \mathrm{ml}$ of carrier) in liquid carriers

\begin{tabular}{|c|c|c|c|c|c|c|c|}
\hline \multirow[b]{2}{*}{$\begin{array}{c}\text { Tr. } \\
\text { No } \\
\text {. }\end{array}$} & \multirow[b]{2}{*}{$\begin{array}{c}\text { Treatmen } \\
\mathbf{t}\end{array}$} & \multicolumn{6}{|c|}{ Months } \\
\hline & & $\begin{array}{c}I \\
(30 \\
\text { days })\end{array}$ & $\begin{array}{c}\text { II } \\
(60 \\
\text { days }) \\
\end{array}$ & $\begin{array}{c}\text { III } \\
(90 \\
\text { days })\end{array}$ & $\begin{array}{c}\text { IV } \\
(120 \\
\text { days })\end{array}$ & $\begin{array}{c}\mathrm{V} \\
(150 \\
\text { days })\end{array}$ & $\begin{array}{c}\text { VI } \\
(180 \\
\text { days })\end{array}$ \\
\hline $\mathrm{T}_{1}$ & $\begin{array}{l}\text { Saline } \\
\text { solution } \\
(10 \%)\end{array}$ & $\begin{array}{l}38.9 \\
6\end{array}$ & 42.06 & $\begin{array}{c}48.1 \\
5\end{array}$ & $\begin{array}{c}60.3 \\
3\end{array}$ & $\begin{array}{c}56.4 \\
6\end{array}$ & $\begin{array}{c}45.4 \\
8\end{array}$ \\
\hline $\mathrm{T}_{2}$ & $\begin{array}{l}\text { Glycerol } \\
(10 \%)\end{array}$ & $\begin{array}{l}26.0 \\
3 \\
\end{array}$ & \begin{tabular}{|c|}
$33 . .6$ \\
5
\end{tabular} & $\begin{array}{c}35.8 \\
3 \\
\end{array}$ & $\begin{array}{c}47.3 \\
3 \\
\end{array}$ & $\begin{array}{c}42.9 \\
5\end{array}$ & $\begin{array}{c}38.8 \\
0\end{array}$ \\
\hline $\mathrm{T}_{3}$ & \begin{tabular}{|l|} 
Carboxy \\
methyl \\
cellulose \\
$(20 \%)$
\end{tabular} & $\begin{array}{l}31.5 \\
5\end{array}$ & 37.10 & $\begin{array}{c}43.7 \\
6\end{array}$ & $\begin{array}{c}55.6 \\
3\end{array}$ & $\begin{array}{c}53.5 \\
8\end{array}$ & $\begin{array}{c}42.7 \\
5\end{array}$ \\
\hline $\mathrm{T}_{4}$ & $\begin{array}{l}\text { Soybean } \\
\text { oil }(40 \%)\end{array}$ & $\begin{array}{l}19.2 \\
3 \\
\end{array}$ & 25.71 & $\begin{array}{c}26.7 \\
4\end{array}$ & $\begin{array}{c}36.1 \\
7\end{array}$ & $\begin{array}{c}33.2 \\
8\end{array}$ & $\begin{array}{c}32.4 \\
0\end{array}$ \\
\hline $\mathrm{T}_{5}$ & \begin{tabular}{|l} 
Paddy \\
bran oil \\
$(40 \%)$
\end{tabular} & $\begin{array}{l}21.8 \\
4\end{array}$ & 24.28 & $\begin{array}{c}25.3 \\
6\end{array}$ & $\begin{array}{c}33.3 \\
5\end{array}$ & $\begin{array}{c}30.4 \\
8\end{array}$ & $\begin{array}{c}21.7 \\
4\end{array}$ \\
\hline $\mathrm{T}_{6}$ & \begin{tabular}{|l} 
Mineral oil \\
$(25 \%)$
\end{tabular} & $\begin{array}{l}17.1 \\
8\end{array}$ & 19.79 & $\begin{array}{c}27.4 \\
4\end{array}$ & $\begin{array}{c}32.6 \\
2\end{array}$ & $\begin{array}{c}32.8 \\
5\end{array}$ & $\begin{array}{c}21.5 \\
1\end{array}$ \\
\hline $\mathrm{T}_{7}$ & $\begin{array}{l}\text { Lignite } \\
(200 \%)\end{array}$ & \begin{tabular}{|l|}
24.2 \\
2
\end{tabular} & 26.97 & \begin{tabular}{|c|}
31.4 \\
4
\end{tabular} & $\begin{array}{c}29.9 \\
4\end{array}$ & $\begin{array}{c}25.7 \\
3\end{array}$ & $\begin{array}{c}21.4 \\
1\end{array}$ \\
\hline $\mathrm{T}_{8}$ & Control & $\begin{array}{l}21.2 \\
8\end{array}$ & 25.32 & $\begin{array}{c}26.5 \\
6\end{array}$ & $\begin{array}{c}30.7 \\
1\end{array}$ & $\begin{array}{c}26.0 \\
3\end{array}$ & $\begin{array}{c}18.5 \\
0\end{array}$ \\
\hline & $F$ test & Sig. & Sig. & Sig. & Sig. & Sig. & Sig. \\
\hline & $\begin{array}{l}\mathrm{SE} \pm \\
(\mathrm{m})\end{array}$ & 1.65 & 1.67 & 1.69 & 1.66 & 1.85 & 1.74 \\
\hline & $\begin{array}{l}\mathrm{CD}(\mathrm{P} \\
= \\
0.01)\end{array}$ & 6.98 & 7.05 & 7.14 & 7.01 & 7.81 & 7.33 \\
\hline
\end{tabular}

Effect of various treatment on root and shoot length of soybean by paper towel method

Seeds of soybean variety JS-335 were treated with liquid based inoculants as described in treatment and inoculated with Bradyrhizobium japonicum for recording shoot length, root length, germination and seedling vigour index by using paper towel method. There were significant differences noticed due to various treatment and data presented in Table 2 reveals that maximum root and shoot length was recorded by $\left(\mathrm{T}_{1}\right)$ 10 per cent saline solution $(11.30 \mathrm{~cm})$ and (
$9.20 \mathrm{~cm}$ ) followed by (T3) 20 per cent carboxy methyl cellulose treatment noticed $(10.33 \mathrm{~cm})$ root length, and $(8.33 \mathrm{~cm})$ shoot length.

The data presented in table 2 showed that treatment $\mathrm{T}_{1}(10$ per cent saline solution) was registered maximum germination percentage i.e. 86 percent which is significantly superior over all the other treatments. Next best treatment $\mathrm{T}_{3}(20$ per cent carboxy methyl cellulose) was registered i.e. 80.33 per cent.

The results recorded in the table 2 reveals that the seedling vigour index of soybean increased significantly in treatment $\mathrm{T}_{1}$ (10 per cent saline solution) i.e. increased by 1756 over uninoculated treatment.

Table-2: Effect of various treatments on root and shoot length of soybean by paper towel method

\begin{tabular}{|c|l|c|c|c|c|}
\hline $\begin{array}{c}\text { Tr. } \\
\text { No. }\end{array}$ & \multicolumn{1}{|c|}{ Treatment } & $\begin{array}{c}\text { Root } \\
\text { length } \\
\text { (cm/p } \\
\mathbf{1 . )}\end{array}$ & $\begin{array}{c}\text { Shoot } \\
\text { length } \\
\text { (cm/p1.) }\end{array}$ & $\begin{array}{c}\text { Ger } \\
\text { mina } \\
\text { tion } \\
\text { (\%) }\end{array}$ & $\begin{array}{c}\text { Seedli } \\
\text { ng } \\
\text { vigour } \\
\text { index }\end{array}$ \\
\hline $\mathrm{T}_{1}$ & $\begin{array}{l}\text { Saline solution } \\
(10 \%)\end{array}$ & 11.30 & 9.2 & 86 & 1756 \\
\hline $\mathrm{T}_{2}$ & Glycerol $(10 \%)$ & 9.43 & 7.16 & 76 & 1286 \\
\hline $\mathrm{T}_{3}$ & $\begin{array}{l}\text { Carboxy methyl } \\
\text { cellulose }(20 \%)\end{array}$ & 10.33 & 8.33 & $\begin{array}{c}80.3 \\
3\end{array}$ & 1498 \\
\hline $\mathrm{T}_{4}$ & $\begin{array}{l}\text { Soybean oil } \\
(40 \%)\end{array}$ & 8.20 & 6.41 & 69 & 1064 \\
\hline $\mathrm{T}_{5}$ & $\begin{array}{l}\text { Paddy bran oil } \\
(40 \%)\end{array}$ & 7.80 & 6.56 & 70.6 & 6 \\
\hline $\mathrm{T}_{6}$ & $\begin{array}{l}\text { Mineral oil } \\
(25 \%)\end{array}$ & 8.12 & 5.9 & 59 & 887 \\
\hline $\mathrm{T}_{7}$ & Lignite $(200 \%)$ & 8.72 & 6.59 & 53 & 895 \\
\hline $\mathrm{T}_{8}$ & Control & 8.62 & 5.8 & 53.6 & 606 \\
\hline $\mathrm{F}$ test & Sig. & Sig. & Sig. & - \\
\hline \multicolumn{2}{|l|}{$\mathrm{SE} \pm(\mathrm{m})$} & 0.52 & 0.40 & & - \\
\hline $\mathrm{CD}(\mathrm{P}=0.01)$ & 2.17 & 1.68 & - & - \\
\hline
\end{tabular}

\section{Effect of carrier on the root length}

The data in respect of root length are given in table 3 plant root length were recorded at 30,45 DAS. It is seen from the data that root length was significantly affected by various treatments over control. The maximum root length $(36.93 \mathrm{~cm})$ was recorded after 45 DAS by 10 per cent saline solution $\left(\mathrm{T}_{1}\right)$. Followed by $\left(\mathrm{T}_{3}\right)$ treatment 20 per cent carboxy methyl cellulose $(35.73 \mathrm{~cm})$ root length was recorded. and it was found to be significantly superior over all other treatment followed by treatment respectively. 
Table-3: Effect of carrier on the root length (cm)

\begin{tabular}{|c|c|c|c|}
\hline $\begin{array}{l}\text { Tr. } \\
\text { No. }\end{array}$ & Treatment & $\begin{array}{c}30 \text { DAS } \\
\text { (cm) }\end{array}$ & $\begin{array}{c}45 \text { DAS } \\
\text { (cm) }\end{array}$ \\
\hline $\mathrm{T}_{1}$ & Saline solution $(10 \%)$ & 24.77 & 36.93 \\
\hline $\mathrm{T}_{2}$ & Glycerol (10\%) & 21.50 & 33.40 \\
\hline $\mathrm{T}_{3}$ & $\begin{array}{l}\text { Carboxy methyl } \\
\text { cellulose }(20 \%)\end{array}$ & 22.79 & 35.73 \\
\hline $\mathrm{T}_{4}$ & Soybean oil $(40 \%)$ & 19.59 & 30.23 \\
\hline $\mathrm{T}_{5}$ & Paddy bran oil (40\%) & 19.65 & 31.40 \\
\hline $\mathrm{T}_{6}$ & Mineral oil $(25 \%)$ & 17.71 & 27.03 \\
\hline $\mathrm{T}_{7}$ & Lignite $(200 \%)$ & 18.86 & 28.40 \\
\hline $\mathrm{T}_{8}$ & Control & 16.87 & 23.70 \\
\hline & F test & Sig. & Sig. \\
\hline & $\mathrm{SE} \pm(\mathrm{m})$ & 1.26 & 2.19 \\
\hline & $\mathrm{CD}(\mathrm{P}=0.05)$ & 3.82 & 6.66 \\
\hline
\end{tabular}

Effect of carrier on number of nodules, Pod number \& 1000 grain weight.

A field experiment was conducted to test the efficacy of the carrier materials on nodulation of soybean crop and the result are tabulated in table 4 the Maximum nodulation was noticed in 10 per cent saline solution (13 nodules/ plant) and it was significantly superior over all other treatment. Maximum number of pods 55.74 was recorded by treatment $\mathrm{T}_{1}$ (10 per cent saline solution) which was significantly superior over another treatment. Maximum seed weight 165.66 gm was recorded by treatment $\mathrm{T}_{1}$ (10 per cent saline solution) which was significantly superior over another treatment

Table-4: Effect of carrier on number of nodules per plant

\begin{tabular}{|c|l|c|c|c|}
\hline $\begin{array}{c}\text { Tr. } \\
\text { No. }\end{array}$ & \multicolumn{1}{|c|}{ Treatment } & $\begin{array}{c}\text { Nodule } \\
\text { Number } \\
\text { / plant }\end{array}$ & $\begin{array}{c}\text { Pods } \\
\text { number } \\
\text { per plant }\end{array}$ & $\begin{array}{c}\mathbf{1 0 0 0} \\
\text { grain } \\
\text { weight } \\
\text { (g) }\end{array}$ \\
\hline $\mathrm{T}_{1}$ & $\begin{array}{l}\text { Saline solution } \\
(10 \%)\end{array}$ & 13.0 & 55.74 & 165.66 \\
\hline $\mathrm{T}_{2}$ & Glycerol (10\%) & 10.66 & 48.73 & 137.66 \\
\hline $\mathrm{T}_{3}$ & $\begin{array}{l}\text { Carboxy methyl } \\
\text { cellulose }(20 \%)\end{array}$ & 11.36 & 53.59 & 147.66 \\
\hline $\mathrm{T}_{4}$ & Soybean oil (40\%) & 7.48 & 41.63 & 143 \\
\hline $\mathrm{T}_{5}$ & $\begin{array}{l}\text { Paddy bran oil } \\
(40 \%)\end{array}$ & 6.55 & 37.12 & 124.66 \\
\hline $\mathrm{T}_{6}$ & Mineral oil (25\%) & 7.89 & 39.61 & 120.33 \\
\hline $\mathrm{T}_{7}$ & Lignite $(200 \%)$ & 8.33 & 46.21 & 121 \\
\hline $\mathrm{T}_{8}$ & Control & 6.33 & 36.56 & 112.66 \\
\hline $\mathrm{F}$ test & $\mathrm{Sig}$. & & \\
\hline $\mathrm{SE} \pm(\mathrm{m})$ & 0.54 & & \\
\hline $\mathrm{CD}(\mathrm{P}=0.05)$ & 1.66 & & \\
\hline
\end{tabular}

\section{Effects of carriers on grain yield of soybean:}

It is seen in Table 5 that grain yield was maximum in $\mathrm{T}_{1}$ (10 per cent saline solution) i.e. $1470.67 \mathrm{~kg}$ per ha then it was followed by $\mathrm{T}_{3}$ (20 per cent carboxy methyl cellulose) and $\mathrm{T}_{2}$ (10 per cent glycerol) i.e. $1267.67 \mathrm{~kg}$ per ha and $1336.67 \mathrm{~kg}$ per ha respectively. It was seen from the data that there was significant difference between all the treatments and saline solution was the superior one among all the treatments.

Table-5. Effect of Carriers on grain yield of soybean

\begin{tabular}{|c|c|c|}
\hline $\begin{array}{l}\text { Tr. } \\
\text { No. }\end{array}$ & Treatment & $\begin{array}{c}\text { grain } \\
\text { yield } \\
\text { (kg/ha) }\end{array}$ \\
\hline $\mathrm{T}_{1}$ & Saline solution $(10 \%)$ & 1470.67 \\
\hline $\mathrm{T}_{2}$ & Glycerol (10\%) & 1267.67 \\
\hline $\mathrm{T}_{3}$ & $\begin{array}{l}\text { Carboxy methyl cellulose } \\
(20 \%)\end{array}$ & 1336.67 \\
\hline $\mathrm{T}_{4}$ & Soybean oil $(40 \%)$ & 1105.67 \\
\hline $\mathrm{T}_{5}$ & Paddy bran oil $(40 \%)$ & 1046.67 \\
\hline $\mathrm{T}_{6}$ & Mineral oil (25\%) & 1086.67 \\
\hline $\mathrm{T}_{7}$ & Lignite $(200 \%)$ & 1091.67 \\
\hline $\mathrm{T}_{8}$ & Control & 962 \\
\hline \multicolumn{2}{|r|}{ F test } & Sig. \\
\hline & $\mathrm{SE} \pm(\mathrm{m})$ & 49.18 \\
\hline & $\mathrm{CD}(\mathrm{P}=0.05)$ & 149.18 \\
\hline
\end{tabular}

\section{Conclusions:}

Lignite, glycerol, carboxy methyl cellulose,saline solution, mineral oil,soybean oil and paddy bran oi are extensively used as carrier for rhizobia. The present investigation was undertaken on "Shelf life of Bradyrhizobium on different liquid based inoculants and Performance on growth and yield of soybean" during 2015. The observation on shelf life of rhizobia with saline solution $60.33 \times 10^{7}$ cells $/ \mathrm{ml}$, seed germination percentage 86 per cent, root length $11.30 \mathrm{~cm} / \mathrm{pl}$ and shoot length 9.20 $\mathrm{cm} / \mathrm{pl}$ using paper towel method and nodulation i.e. 13 nodules/plant, root length, number of pods, 1000 grain weight were recorded. Similarly different carriers were also tested for shelf life of Rhizobium The maximum seedling vigour index 1756 in 10 per cent saline solution. 


\section{References:}

Anonymous, 2014. Annual Report Departm ent of Agriculture and Cooperation, Ministry of Agriculture GOI. 2015.Economic Survey of Mahrastra.www.mahaagri.nic.in.

Brahamprakash, G.P. and S. Velineni, 2011. Survival and phosphate solubilizing ability of Bacillus megaterium in liquid inoculants under high temperature and desiccation stress. Deparment of Agri. Microbiology. 14 (5): 795-802.

Biswas, P. K. and M. K. Bhowmick. 2007. Effect of liquid and carrier base Rhizobium inoculant on growth regulation and seed yield of urdbean. Crop and Weed. 3 (2): 7-9. Burton, J. C. and R. L. Curley, 1965. Comparative efficiency of liquid and peatbase inoculants on field grown of soybean (Glycine max). Agron. J. 57: 339-381.

Chore, C. N. and N. R. Shastri, 1991. Study of soybean (Glycine max L.Merrill) to Rhizobium culture. J. Soil and Crops.1 (2): 162-164.

Ingle, Y. V. 2001. Studies on associative effect of Azospirillum brasilence on soybean (Glycine $\max$ (L.) Merrill). M.Sc. Thesis (unpub.), Dr. PDKV. Akola.

Kurundkar, B. P., P. A. Thombre and B. R. Kawale, 1991. Effect of different inoculums levels of Bradyrhizobium japonicum on soybean. Legume Res. 14 (4): 201-204.
Mahaveer, P. Sharma, K. Sushil, Sharma and Alok Dwivedi, 2010. Liquid biofertilizer application in soybean and regulatory mechanisms. Agri. Today, April issue, 44-45.

Panlada, T. W. and Payakapong, 2007. Growth survival and field performance of Bradyrhizobium liquid inoculants formulation with polymeric additives. Sci. Asia. 33: 69-77.

Rao, D. L. 2008. Improvement in formulation and shelf life of consortia of microorganism. Biofertilizer Newsletter, TNAU Coimbatore: 4-5.

Sridhar, V., G. P. Brahmaprakash, and S. V. Hegde, 2004. Development of liquid Inoculant using for phosphate solubilizing bacterium. Karnataka J. Agric. Sci.17 (2): 251-257.

Tran Yen Thao, Poul W. Singleton and David Herridge, 2002. Inoculation responses of soybean and liquid inoculant as an alternative to peat-based inoculant. Inoculants and Nitrogen Fixation of Legumes in Vietnam. 106: 67-74. 